\title{
Cooperative Learning for Students' Positive Performance in English Language Courses at University Level (Case Study of Bakht E-Ruda University Students)
}

\author{
Dr. Elrayah Eltahir Adam Khatir \\ Assistant Professor of English, Faculty of Education, University of Bakht-Er- Ruda, Sudan- Gassim University KSA
}

\begin{abstract}
The study aimed to identify the effect of using cooperative learning strategy on students learning of English language courses at university level in Sudan, where the sample of the study consisted of (40) students from Bakht E-Ruda University at white Nile state in Sudan who were divided into experimental group and control group. The researcher used the normal course assessment as tools to analyse the students performance. the result of the study showed that using cooperative learning stimulate students to learn and help them to have positive achievement in university English language courses as well as developing the social skills of the students.
\end{abstract}

Keywords:

\section{Introduction}

It is well known than cooperative learning is not only increasing the study skills of the student but is also interesting and open enough for the group of students. students get familiar with listening to each other as well as sharing information, which is a necessary step in learning. The main challenge behind cooperative learning is that it needs to be planned in such a way that it fits perfectly and the students gain positively from it. For example, it can happen sometime that the students in a group are noisy and all the workload is shifted onto one student, in such a case you can either change the activity or reconsider your seating plan in order to neutralize the class dynamics. Another important aspect in cooperative learning is that of motivation. When the students get into some task, motivation is a great necessity in order for them to proceed successfully. If they are motivated, they get new ideas, which they are eager to share with their group members and as this continues, each student gets more into the topic. In cases when students are allowed to pick up their own topic, they are opened to more opportunities for learning as they get to benefit from finding out more about their chosen topic. One of the most important aspects of cooperative learning is to teach those students how to work in groups who are not familiar with this type of learning. So it is the researcher's intention to bring cooperative learning into focus of practice and implement it into three course of English language and discover its effectiveness.

\section{Objectives of the Study}

The study aims at finding out the effect of co-operative learning in facilitating learning process of different courses at university level. To see after the implantation of the cooperative learning in the three courses whether it help in the development of the students' positive performance or not. as teaching methods to increase student achievement. Therefore, the purpose of this study is to test the hypothesis: university students who participate in cooperative learning structures will gain higher curriculum-based assessment scores than students who do not use this method of learning.

\subsection{Question of the Study}

The core question of the study is:

Are there statistical significance differences between the level of achievement for experimental and control groups in different tests of the courses under study?

\section{Delimitation of the Study:}

This study is limited to Bakht E-Ruda University at white Nile state in Sudan then it can be generalized for all universities in Sudan. So the population are university students in Sudan specifically Bakht Alruda University students of the third year (semester six) in the year (20142015). It is also limited to the three courses advanced phonetics, psycholinguistics and advanced reading skills.

\section{Literature Review}

\section{Introduction}

The best education systems train their teachers rigorously at the outset, focusing particularly on the practical teaching skills they will need. At each stage of their career, and especially as they move into leadership positions, teachers in the highest performing systems receive further focused training and development ((Barber and Mourshed (2007), Auguste, B., Kihn, P., Miller, M., (2010)).

In the highest performing countries, teachers and teaching are held in the highest esteem. Rightly so, because all the evidence shows that good teachers make a profound difference. Studies in the United States have shown that an individual pupil taught for three consecutive years by a teacher in the top ten per cent of performance can make as much as two years more progress than a pupil taught for the same period by a teacher in the bottom ten per cent of performance (Sanders, W. L., and Rivers, J. C. 1996). 


\section{International Journal of Science and Research (IJSR) \\ ISSN (Online): 2319-7064 \\ Index Copernicus Value (2013): 6.14 | Impact Factor (2014): 5.611}

Teaching a language in a foreign context has some potential difficulties. Inevitably, such challenges should be uncovered to find solutions for the improvement of the situation. Thus, the constant communication with learners and teachers as being the immediate agents of problems is one of the main duties of the Ministry of Education. For researchers in the field of English language teaching and training, the basic duty is to observe, find, identify and determine these problems through dialogues with English language teachers regarding the classroom situations. Hence, they are the ones who are able to generate some suggestions and solutions to the difficulties experienced by English language teachers and students contributing to the ease of connection of the ministry to the schools (Dörnyei, Z. 2001).

Most of the teaching in the EFL classroom still emphasizes teacher-centered, teacher-directed instruction. With a crowded class in teaching, teachers still make use of the traditional teaching methods; there is little interaction among teachers and students. Naturally, the teacher usually spends a lot of time speaking and explaining curriculum in class. Students are required to sit in their seats passively and listen to the lecture attentively. Students tend to memorize English grammar rules, rote vocabulary, and translation skills from the textbooks (Liu, 1997; Wang, 2001).

In these recent days, cooperative teaching is applied in almost all school content areas and, progressively more, in college and university environments all over the world, and is claimed to be an effective teaching method in foreign and second language education by scholars abroad. As well, it is generally declared that cooperative teaching approach is the finest option for all learners because it accentuates energetic interaction among students of diverse abilities and backgrounds and reveals more positive student results in academic achievement, social behavior, and affective development (Nelson, 1993).

Cooperation in Teaching English as a Foreign Language: Cooperative education has shown to be an effectual technique for teachers and their students. Cooperative teaching activities allow those young learners to have more potential and opportunities to put into practice all of the knowledge that they have studied, as well as to improve their social and learning skills (Jacobs \& McCafferty, 2006). It is also capable of helping students in improving their skills in oral communication (Slavin, 1995). Additionally, cooperative teaching is a highly significant teaching method which proposes an opportunity for those groups of students to work interdependently and obtain feedback from others (Jacobs \& McCafferty, 2006). It is essential to apply the cooperative teaching method in English as a foreign language classes.

The cooperative group is generally three to four students who are joined by a common goal in order to achieve the task and to incorporate with each and every group member. Cooperative groups are appropriate for all ages, subject areas, and types of students. Regardless of age, almost everyone loves to socialise, be with others, and to work together (Rimmerman, 1996).

One fear English language teachers have in concern of using cooperative teaching method is that low status students will not take part or that high status students will take over the group. Therefore, English language Teachers must form groups which are reasonable so that all students participate fully and use multiple-ability strategies (Cohen, 1998) if cooperative teaching is to work. Cohen (1998) mentioned that teachers also must convince their students of three things: those unusual intellectual abilities are involved in cooperative learning, that no one student has all of the abilities needed, but that each member of the group will have some of the abilities.

\section{Elements of Cooperative Teaching: \\ 1) Positive Independence}

Positive interdependence is generating the sense that group members study the given material and guarantee that all members of the group learn the assigned material. Group members have to identify that they connect to each other in a way or another, in which one cannot thrive except if everyone succeeds (Johnson \& Johnson, 1994).

\section{2) Face-to- Face Interaction}

Face-to-face communication is described by Johnson and Johnson (1994), as students promote and help each other's, make efforts to accomplish, complete tasks, and generate in order to get to the group's main objectives. Face-to-face interaction is also considered as a way which through encouraging and motivating communication among students, where members turn out to be personally committed to each other as well as to their joint goals (Glanz, 2004).

\section{3) Individual Accountability}

Individual accountability is the aspect that provided for each member of a group to evaluate against a standard and hold responsibility for their contribution to achieve goals (Johnson \& Johnson, 1994). Individual accountability is the solution to guarantee that each group member is reinforced throughout group work. The existences of individual accountability permits students have more motivation to learn (Kagan \& Kagan, 1998).

\section{4) Interpersonal and Small Group Skill}

The interpersonal and small group skill is regarding teachers giving beneficial response, reaching an agreement, and relating to each and every member, which is significant for efficient group functioning (Johnson \& Johnson, 1994). When those learners take part repeatedly in cooperative activities, all students get enduring intellectual abilities (Huss, 2006).

\section{Teacher's Roles in Cooperative Learning}

Teachers' role is considered as an important aspect in assisting groups to function well. In a cooperative learning classroom, teachers ought to be facilitators, guide on the side and take more skills than they use teacher-fronted instruction (Zhang, 2010). Teachers speak fewer than in teacher-fronted classes (Jocob, 2006). They arrange students for the assigned tasks which they will carry out, in addition, they support students with the learning assignment, and they give less command, imposing less disciplinary control (Harel, 1992).

\section{Volume 4 Issue 12, December 2015}




\section{International Journal of Science and Research (IJSR) \\ ISSN (Online): 2319-7064 \\ Index Copernicus Value (2013): 6.14 | Impact Factor (2014): 5.611}

Students' Roles in Cooperative Learning

A student has five roles in a cooperative class: (a) facilitator: which is the students who is responsible of coordinating the group's works; (b) recorder: whose duty is recording what the group has achieved; (c) reporter: who is responsible to tell the students about the group's work; (d) timekeeper: whose duty is to help his/her group to be fully prepared of time constraints, and follows up with the group in accomplishing their tasks, as well as the responsibility to fill in for missing group members; (e) observer: which observes collaborative skill, and makes sure that group members are using a specific collaborative skill deemed important to the group's interaction (Jacob, 2006).

\section{Methodology}

The researcher used descriptive analytical approach to achieve the goal of the study, which is based on the data collection, classification, organization and analysis.

\section{Study Population}

The Population of the study consists of all university students Bakht E-Ruda University at White Nile state in Sudan College of education students in the year (2014-2015)

\section{Study Sample}

Study sample consists of (40) students who specialized in English language in the college of education at Bakht E-Ruda University at white Nile state in Sudan . They were selected randomly using the odd numbers from all the students in the list and then the first forty numbers represent the group of the study. They are divided into two groups. 20 of them subjected to the co-operative learning strategy and the other 20 used the traditional method of lecturing . then the results compared at the end of the semester to discover the effect of co-operative for the students.

\section{Study Tools}

To achieve the goal of the study the researcher used the normal assessments tools the students in the college. They are $1^{\text {st }}$ test, $2^{\text {nd }}$ test, assignments homework and the final examination. Then the general results percentage of the students compared to discover the effect of the cooperative learning for the students promotion during the semester.

\section{Discussion}

The purpose of the study was to determine if the students at Bakht Alruda University College of education in the three courses (psycholinguistics, advanced writing and advanced phonetics) who participated in cooperative learning structures would gain higher curriculum-based assessment scores than students who did not use this method of learning. Both controlled and treatment group students' scores from each assessment were recorded. A class general percentage was calculated in tables one and two in the appendix. The percentage used the following formula:

\section{Aggregate marks accounting to students $/$ numbers}

Actual aggregate of marks

The control group results are:

\begin{tabular}{|c|c|c|}
\hline sociolinguistics & Advanced writing & Phonetics \\
\hline $\mathbf{7 4 . 4 \%}$ & $\mathbf{6 5 . 5} \%$ & $\mathbf{6 7 \%}$ \\
\hline
\end{tabular}

The experimental group results are:

\begin{tabular}{|c|c|c|}
\hline sociolinguistics & Advanced writing & Phonetics \\
\hline $\mathbf{9 0 . 8} \%$ & $\mathbf{8 5 . 3 5 \%}$ & $\mathbf{8 7 . 1 \%}$ \\
\hline
\end{tabular}

The primary goal of this study was to measure student achievement for those using cooperative learning structures as a method of instruction and to compare that achievement with those using a traditional lecture/independent style of instruction. For each assessment, the assumption that using cooperative learning structures would result in higher achievement was proven as in the table above. Although the intent did not focus on measuring achievement for students with disabilities, the results indicate that cooperative learning structures can be used successfully for students of diverse abilities. All students with different abilities in the treatment group were more successful than those in the control group. A goal of placing students with disabilities in an inclusive setting is to foster acceptance and increase social interaction. cooperative learning address this issue due to the inherent nature of the heterogeneous groupings. This goal was reached according to the teacher's observations of social interactions within the groups. The social context of the group helped avoid the isolation from participation in the course. These findings have relevance to the general classroom teacher faced with implementing inclusion of students with special needs. Cooperative learning structures can be easily used as a modification to instruction with no extra time or effort required of the teacher. One lesson plan using cooperative learning structures has built in peer tutoring and support within the heterogeneous class groupings, which eliminates the requirement for several different plans to meet the needs of all students. Because structures are content free, this method of cooperative learning could be adapted to any curricular area and any level. In this study the sixth grade social studies textbook was the foundation for instruction. A limitation of the study could be the differences in students within each class period. Although efforts were made to ensure that each class period contained students of comparable abilities, the group make-up could have affected the outcomes. The control group did score lower on each assessment.

\section{Summary, Results and Recommendations}

\section{Summary}

The results of the study show that there are statistically significant differences in the academic achievement between experimental and control group between the traditional way and the cooperative learning in favors of the cooperative learning. That react the effectiveness of using cooperative learning in teaching English university courses. The study proved the effect of using of cooperative learning in developing the students skills through creative reading and using cooperative in teaching gives students motivation to develop their learning outcomes.

\section{Results of the Study}

Due to the analysis of the study, the research comes to the following results: 


\section{International Journal of Science and Research (IJSR) \\ ISSN (Online): 2319-7064 \\ Index Copernicus Value (2013): 6.14 | Impact Factor (2014): 5.611}

- Cooperative learning enhance students' abilities in different courses.

- Cooperative learning motivate students to work together to achieve their learning aims.

- Cooperative learning motivate students to give in their best effort to achieve the group's success.

- Cooperative learning motivate students to work on their social interactions.

- With cooperative learning, learners will be motivated to understand the contents of their courses.

- With cooperative learning students learn better because they are enjoying themselves. With the idea that "the best students are the happiest students."

- Cooperative learning conduct the Classroom Action Research and that open a new horizon on learning English.

\section{The Conclusion}

The study revealed the followings:

- The study showed the advantages of the Cooperative learning in developing the students' ability in achieving the goals of the English courses .

- The students results ensure the development of their different university courses through Cooperative learning .The teacher involved in this study was an experienced teacher with an interest and background in cooperative learning that received continual support and feedback from trainers and other teachers using the cooperative learning structures.

\section{Recommendations of the study}

The researcher presents the following recommendations on the light of the results of the study.

- Co-operative learning must be used in Sudanese universities because they because it is better than the traditional way followed in universities..

- Teachers should be trained to use cooperative leaning in teaching English at Sudanese universities.

- Teachers should be encouraged to use co-operative learning in Sudanese universities specifically in teaching English language courses.

- There must be work on implementing the yearly, quarterly and daily plans different cooperative learning appropriate with teaching English language courses.

- Conducting another studies to recognize the effects of cooperative learning and the effectiveness in the different universities in another university courses in other fields.

- Cooperative learning should be taught prior to beginning cooperative learning lessons.

- The results could be quite different if the teacher were inexperienced, not committed to using structures, or did not receive support.

\section{Reference}

[1] Barber and Mourshed (2007). Auguste, B., Kihn, P., Miller, M. (2010), closing the talent gap: Attracting and retaining top-third graduates to careers in teaching - An international and market research-based perspective, McKinsey and Company.
[2] Bloom, B.S. (1964/ Stability and Change in Human Characteristics. New York: Wiley.

[3] Brecke, R., \& Jensen, J. (2007). Cooperative learning, responsibility, ambiguity, controversy and support in motivating students. Insight: A Journal of Scholarly Teaching, 2(1), 57-63.

[4] Cohen, E.G. \& Benton, J. (1988). Making group work. American Educator, 12, 10-17, 45-46.

[5] Cohen, E.G. (1998). Making cooperative learning equitable. (Realizing a positive school climate.) Association for Supervision and Curriculum Development.

[6] Dornyei, Z. (2001). Motivational strategies in the language classroom. Cambridge: Cambridge University Press.

[7] Glanz, J. (2004). Teaching 101: classroom strategies for the beginning teacher. Thousand Oaks, CA: Corwin Press.

[8] Glanz, J. (2004). Teaching 101: classroom strategies for the beginning teacher. Thousand Oaks, CA: Corwin Press.

[9] Harel, Y. (1992). Teacher talk in the cooperative learning classroom. In C. Kessler (Ed.), Cooperative language learning: A teacher's resource book (pp.153162). New York: Prentice Hall.

[10]Huss, J. A. (2006). Gifted education and cooperative learning: A miss or a match? Gifted Child Today, 29(4), 19-23. doi:10.4219/gct-2006-13

[11] Jacobs, G. (2006). Connections between cooperative learning and second language learning and teaching, (pp. 18-29). Cambridge University Press.

[12] Johnson, D. W., Johnson, R. T., \& Smith, K. A. (1998). Cooperative learning returns to college: What evidence is there that it works? Change, 30(4), 26-35.

[13] Johnson, D. W., Johnson, R. T., \& Stanne, M. B. (2000). Cooperative Learning Methods: A metaanalysis. Retrieved July, 2000 from the World Wide Web: http://www.clcrc.com/pages/cl-methods.html.

[14] Johnson, D., \& Johnson, R. "Cooperative Learning." [Online] Retrieved 15 October 2001 from http://www.clcrc.com/pages/cl.html.

[15] Johnson, D.W. \& Johnson R.T. (1999). Learning Together and Alone: Cooperative, Competitive, and Individualistic Learning (5th Ed.) Boston: Allyn and Bacon.

[16] Johnson, D.W. \& Johnson, R.T. (1989). Cooperative learning: What special educators need to know. The Pointer, 33, 5-10.

[17] Johnson, D.W., Johnson, R.T.\& Holubec, E.J. (1993). Circles of learning: Cooperation in the Classroom (4th Ed.).Edina, MN: Interaction Books.

[18]Kagan, S. (1990). Cooperative learning resources for teachers. San Juan Capistrano, CA: Resources for Teachers.

[19] Rimmerman, H. (Ed.)(1996). Resources in cooperative learning. San Juan, CA.

[20] Slavin, R. E. (1978). Student Teams and Achievement Divisions. Journal of Research and Development in Education, 12, 39-49.

[21] Slavin, R. E. (1990). Cooperative learning: Theory, research and practice. New Jersey: Prentice Hall. 


\section{International Journal of Science and Research (IJSR) \\ ISSN (Online): 2319-7064 \\ Index Copernicus Value (2013): 6.14 | Impact Factor (2014): 5.611}

[22]Zhang, Y. (2010). Cooperative language learning and Language Teaching and Research, 81-83

foreign language learning and teaching. Journal of

Appendix

Table 1: The general percentage of students' achievement in the control group

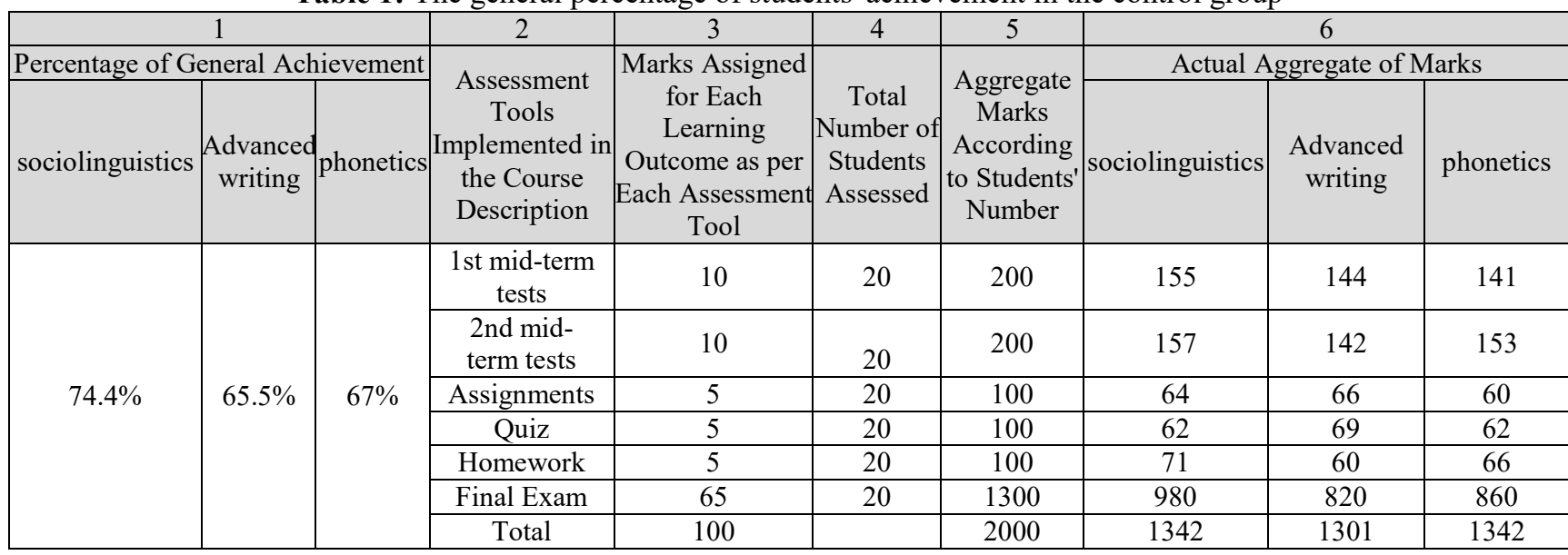

Table 2: The general percentage of students' achievement in the experimental group

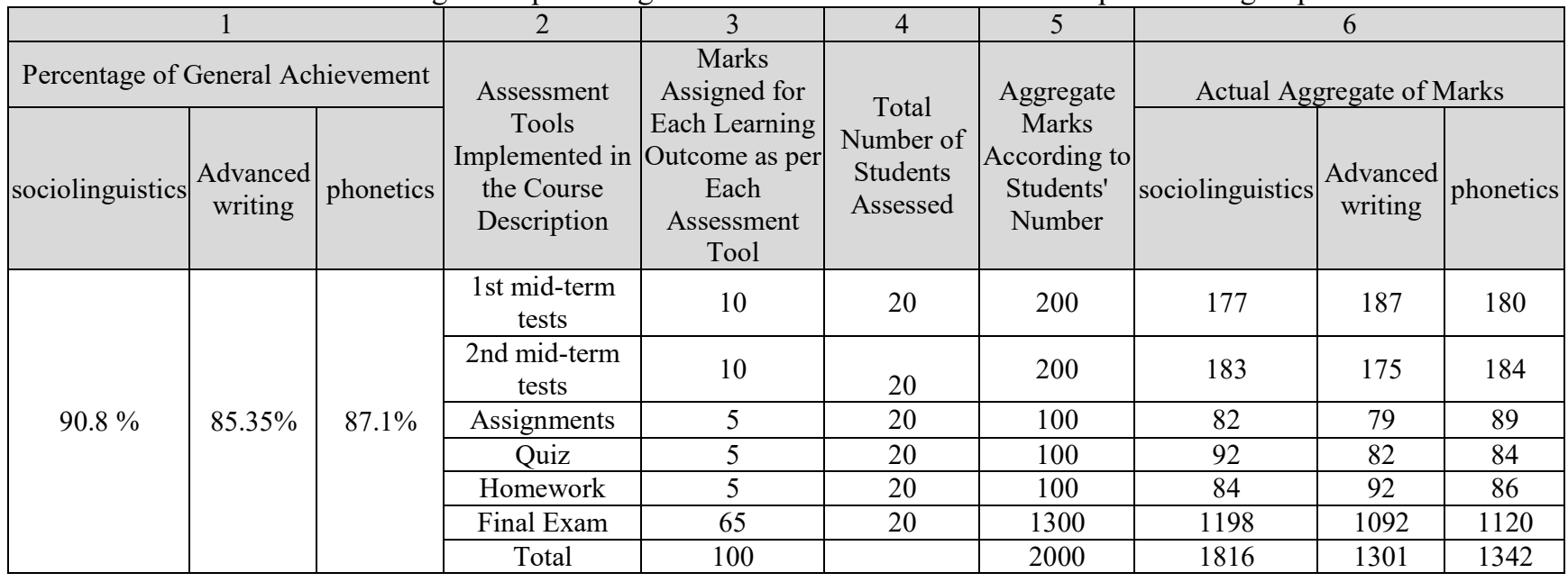

